\title{
PENERAPAN MODEL OPEN ENDED PROBLEMS BERBANTUAN VIDEO PEMBELAJARAN UNTUK MENINGKATKAN KEMAMPUAN BERPIKIR KREATIF SISWA KELAS 2 SD MUHAMMADIYAH 3 SURABAYA
}

\author{
Putri Hesti Wulandari ${ }^{1}$, Deni Adi Putra ${ }^{2}$, Meirza Nanda Faradita ${ }^{3}$ \\ ${ }^{1}$ Universitas Muhammadiyah Surabaya \\ Email: putri.hesti.wulandari-2020@fkip.um-surabaya.ac.id \\ ${ }^{2}$ Universitas Muhammadiyah Surabaya \\ Email: deniadiputra@fkip.um-surabaya.ac.id \\ ${ }^{3}$ Universitas Muhammadiyah Surabaya \\ Email: meirzaananda@fkip.um-surabaya.ac.id
}

\begin{abstract}
Abstrak
Penelitian ini bertujuan untuk mendeskripsikan proses pembelajaran model Open Ended Problems berbantuan media video pembelajaran, siswa mampu menyampaikan ide atau pendapat, mampu menjawab setiap permasalahan pada pembelajaran matematika. Metode penelitian yang digunakan jenis PTK (Penilaian Tindakan Kelas), analisis data menggunakan deskriptif, subjek penelitian ini adalah siswa kelas 2 SD Muhammadiyah 3 Surabaya. Penelitian ini dilakukan dua siklus, sebelum masuk siklus penelitian, terdapat tahap awal dengan observasi. Hasil dari penelitian ini dari proses penerapan Open Ended Problems pada tahap awal tidak ada penerapan model pembelajaran apapun di kelas 2 SD Muhammadiyah 3 Surabaya, sehingga siswa pasif dalam pembelajaran. Pada siklus 1, siswa mulai aktif dalam menyampaikan ide atau pendapat mereka, pada siklus 2 terdapat progres yang sangat baik, hampir keseluruhan siswa timbul rasa percaya diri untuk menyampaikan ide atau pendapat mereka dan mulai menanggapi setiap pertanyaan. Terlihat juga adanya perubahan berpikir kreatif siswa pada siklus 1 sebesar $46,15 \%$ dengan mencapai nilai indikator kriteria penilaian 75 dan pada siklus 2 sebesar 80,76\% dengan mencapai indikator kriteria penilaian yakni 95. Hasil tersebut telah menunjukkan bahwa dengan menerapkan model Open Ended Problems berbantuan media video pembelajaran meningkatkan berpikir kreatif siswa kelas 2 SD Muhammadiyah 3 Surabaya.
\end{abstract}

Kata kunci: Model Open Ended Problems, Berpikir Kreatif, Progres.

\begin{abstract}
This study aims to describe the model of learning process namely Open-Ended Problems with the help of learning videos as the media, to stimulate the students are be able to deliver their ideas or opinion, as well as answering every problem in math. The method uses is based on Class Activity Evaluation, with descriptive data analysis, and the subjects are the second-grade students of SD Muhammadiyah 3 Surabaya. The research is conducted with two cycles, but before doing the cycles, the researchers also run the observation. The results of this research from the application of Open-Ended Problems at the first phase are that there are not any of learning models in second-grade of SD Muhammadiyah 3 Surabaya, so that the students are passif in the class. After the first cycle is applied, the students increasingly active to delivrer their opinions and ideas, then on the second cycle there are excellent progress that almost all of the students have the confidence to deliver the ideas and opinions and they also start to respond in every question. It is also appeared that there is an enhancement of students' creative thinking on the first phase around $46,15 \%$ with the reach of evaluation indicators criteria at 75 , and on the second phase are $80,76 \%$ with the reach of evaluation indicators criteria at 95 . Those results represent that by applying the model of Open-Ended Problems with the helps of learning videos as the media can increase creative thinking skills of the second-grade students of SD Muhammadiyah 3 Surabaya
\end{abstract}

Keywords: Model Open Ended Problems, Creative Thinking, Progress. 


\section{PENDAHULUAN}

Pendidikan adalah suatu hal yang penting bagi setiap manusia. Pendidikan dapat memberikan pengaruh bagi manusia itu sendiri. Tanpa adanya Pendidikan bisa kehilangan arah dalam hidupnya. Dengan demikian pendidikan merupakan suatu kegiatan yang dilakukan dengan sadar untuk mewujudkan suasana belajar secara aktif melalui kegiatan bimbingan dan latihan bagi peranannya dimasa yang akan datang, (Putranti et al., 2021).

Pendidikan yang ada dan sering diberikan di lapangan, seperti hal nya mata pelajaran matematika, pelajaran matematika merupakan pembahasan penting untuk diberikan kepada semua siswa sebagai bekal siswa dengan

kemampuan berpikir logis, analitis, sistematis, kretaif, kritis, serta mampu bekerja sama. Menurut (Abdurrahman, 2003) terkait pembelajaran matematika seyogyanya harus diberikan kepada siswa karena, matematika sering digunakan dalam keseharian, semua mata pelajaran memerlukan keterampilan matematika yang sesuai, sebagai sarana komunikasi yang jelas, untuk menyajikan informasi dalam berbagai cara, dapat meningkatkan kemampuan berpikir logis, jelas, dan memberikan solusi terhadap permasalahan yang dihadapi.

Pembelajaran matematika masih menekankan pada penghafalan rumus dan menghitung, hal ini menyebabkan kemampuan berpikir kreatif siswa kurang(Pujiati et al., 2018). Perihal ini juga terjadi pada siswa SD Gugus 2 Kecamatan Lubuk Basung, yang mana siswa masih belum terbiasa menyelesaikan permasalahan dengan cara mereka sendiri. sehingga kemampuan berpikir kreatif siswa tidak bisa berkembang dengan baik,(Wanelly \& Fauzan, 2020). Dalam hal ini sering terjadi pada pembelajaran kelas bawah lebih tepatnya di kelas 2 SD.

Perihal karakter siswa kategori kelas bawah atau kelas 2 SD peneliti menemukan, kebanyakan dari mereka perlu suatu dorongan untuk meningkatkan daya berpikir kreatif dalam diri mereka masing - masing. Sebab, siswa tidak terlalu banyak interaksi, pasif, dan tidak berkembang dalam pembelajaran matematika, padahal seusia mereka yang sedang mengalami perkembangan memiliki kondisi fisik yang bagus serta mudah menangkap pelajaran. Hal ini sejalan dengan penjelasan dari (Kawuryan, 2013), siswa kelas bawah terutama kelas 2 SD masih sangat membutuhkan perhatian dari guru 
karena kefokusan dalam hal konsentrasi masih kurang. Selain itu, sisi tanggap dan respon dari siswa kelas $2 \mathrm{SD}$ terhadap motivasi belajar juga masih rendah. Hal ini memerlukan peranan aktif guru dalam menciptakan proses belajar yang lebih menarik dan efektif. Dengan demikian seluruh potensi yang dimiliki siswa perlu didorong untuk berkembang secara optimal dalam berpikir kreatif.

\section{Berdasarkan hasil observasi}

peneliti di kelas 2 SD Muhammadiyah 3 Surabaya menemukan beberapa kendala dalam proses pembelajaran diantaranya, model pembelajaran yang masih jarang diterapkan, media yang cenderung monoton, keterbatasan sumber belajar, dan beberapa siswa masih cenderung pasif dalam proses pembelajaran maupun diskusi. Dalam proses diskusi masih ditemukan siswa yang bermain sendiri bahkan mengganggu teman sebelahnya. Selain itu, kemampuan berpikir kreatif siswa masih rendah. Berdasarkan hasil evaluasi prasiklus pada aspek pengetahuan, menunjukkan bahwa dari 26 siswa kelas 2 sebanyak 19 siswa mendapat nilai dibawah KKM sedangkan 6 siswa sudah mencapai KKM. Hal ini dikarenakan siswa yang masih menggunakan metode ceramah untuk proses pembelajaran. Oleh sebab itu, kemampuan berpikir kreatif dalam proses pembelajaran perlu ditingkatkan dan dikembangkan oleh siswa dengan menerapan model pembelajaran yang sesuai serta penggunaan media inovatif yang dapat memberikan stimulus kepada siswa untuk bisa membuka pola pikir mereka dalam memahami suatu permasalahan, sehingga dapat meningkat minat dan aktivitas belajar siswa.

Model pembelajaran merupakan faktor yang dapat mempengaruhi hasil belajar siswa karena merupakan perencanaan yang akan digunakan dalam proses pembelajaran, Rohmah (Putranti et al., 2021) solusi untuk meningkatkan kemampuan berpikir kreatif yakni dengan menerapkan model pembelajaran Open Ended Problems berbantuan media video pembelajaran.

Model pembelajaran Open Ended Problems berbantuan media video pembelajaran dapat meningkatkan kemampuan berpikir kreatif siswa. Dengan menggunakan media video pembelajaran dapat memberikan stimulus kepada siswa untuk berpikir kreatif dan berkonsentrasi pada media tersebut. Video pembelajaran dapat ditayangkan kepada siswa untuk disaksikan secara bersama - sama agar meningkatkan rasa bersatu antar siswa, 
lalu ada interaksi yang baik dalam proses pembelajaran. Melalui model Open Ended Problems berbantuan media video pembelajaran diharapkan proses pembelajaran dapat lebih menyenangkan dan siswa aktif untuk berpikir kreatif, melatih dan menumbuhkan kemurnian pemikiran, kreatifitas, kognitif tinggi, kritis, komunikasi, interaksi, sharing keterbukaan dan sosialisasi, (Suyanto, 2009).

Model pembelajaran Open Ended Problems merupakan pendekatan dengan membuka kesempatan kepada siswa untuk memahami berbagai strategi dan cara yang dijalankan sesuai dengan kemampuan menafsirkan permasalahan. (Taufik, 2012). Pendekatan Open Ended Problems memberikan kesempatan pada siswa untuk menjawab berbagai permasalahan melalui berbagai strategi dalam hal mendorong pemikiran kreatif siswa dan matematis dalam memecahkan masalah. Siswa memiliki kesempatan untuk mengungkapkan ide atau gagasannya. Kemampuan berpikir kreatif dapat diterapkan melalui pendekatan Open Ended Problems dengan memberi motivasi siswa agar aktif dalam pembelajaran dan mengemukakan ide dengan berbagai cara. (Wanelly \& Fauzan, 2020).
Pengertian video yakni teknologi pengiriman sinyal elektronik dari suatu gambar yang bergerak. Video mampu menggabungkan teknologi audio dan visual secara bersama sehingga menghasilkan suatu tayangan yang dinamis dan menarik, (Yudianto, 2017). Menggunakan video sebagai media untuk meningkatkan inovasi dalam mengkombinasikan antara suara dan gambar serta dikemas dengan berbagai bentuk. Misalnya, menggunakan teks, audio dan musik. Menurut Sudjana dan Rivai (Yudianto, 2017) manfaat penggunaan media video yaitu, dapat menumbuhkan motivasi dalam diri setiap individu, memiliki pesan yang bisa disampaikan dengan jelas sehingga dapat dipahami oleh siswa dan memungkinkan terjadinya pencapaian tujuan penyampaian pesan. Jadi, pembelajaran akan lebih cepat ditangkap dan dipahami oleh siswa untuk memahami pembelajaran matematika serta memotivasi siswa untuk bisa menstimulus daya pikir kreatif dalam diri mereka masing - masing.

Berpikir kreatif menurut Krulik (Ramadhani \& Nuryanis, 2017) yakni pemikiran yang murni dengan memberikan penjelasan yang detail meliputi rumusan ide dan efektif ide tersebut. Kemampuan berpikir kreatif 
dianggap penting dalam pembelajaran, hal ini dikarenakan siswa dapat menyelesaikan berbagai persoalan dengan berbagai sudut pandang dan konsep yang berbeda. Pentingnya berpikir kreatif menurut Munandar (Nada et al., 2018) didasarkan pada empat alasan, yaitu kemampuan kreatif menjadikan seseorang dapat mengaktualisasikan dirinya sendiri, kemampuan berpikir kreatif sebagai kemampuan yang membuat manusia mampu meningkatkan kualitas hidupnya, mampu memberi kepuasan pada individu dan berpikir kreatif juga menjadikan seseorang dapat melihat beragam kemungkinan untuk menyelesaikan masalah.

Penelitian pada jurnal yang dilakukan oleh (Wanelly \& Fauzan, 2020) tentang model pendekatan Open Ended dan belajar siswa terhadap kemampuan berpikir kreatif, kemampuan berpikir kreatif siswa dalam pembelajaran dengan pendekatan Open Ended lebih baik dari pada siswa yang mendapatkan pengajaran dengan cara konvensional. Disamping itu, dengan cara belajar auditorial, visual dan kinestetik tidak terdapat perbedaan, kemampuan berpikir kreatif antara cara belajar visual, auditorial, dan kinestetik. Serta tidak terdapat interaksi antara pendekatan pembelajaran dan cara belajar dalam mempengaruhi kemampuan berpikir kreatif siswa.

Selain itu hasil jurnal dari (F. M. Amir \& Wardana, 2017; M. F. Amir \& Wardana, 2017), menggunakan media domino pecahan berbasis Open Ended dalam meningkatkan kemampuan berpikir kreatif siswa SD, menjelaskan kartu domica berbasis Open Ended hasil uji coba mampu meningkatkan target hasil belajar siswa sebesar 71,26\% atau 27 siswa dari 40 siswa yang sangat kreatif dan kreatif. Dengan kedua peneliti sebelumnya sudah melakukan tindakan yang menghasilkan penelitian lebih baik. Maka dari perbedaan peneliti sebelumnya, peneliti mengambil penelitian penggunaan media video untuk meningkatkan keterampilan berpikir kreatif siswa kelas 2 SD Muhammadiyah 3 Surabaya.

Berdasarkan uraian-uraian di atas tujuan dari penelitian ini adalah dengan proses penerapan pembelajaran model Open Ended Problems berbantuan media video pembelajaran yang menyajikan suatu permasalahan dengan memiliki penyelesaian masalah lebih dari satu menurut (Biliya A, 2015), siswa dapat menyampaikan ide atau pendapat mereka, siswa mampu menjawab setiap permasalahan pada 
pembelajaran matematika. Selain itu, adanya peningkatan terhadap kemampuan berpikir kreatif pada siswa, dapat dikembangkan secara continue pada setiap materi yang berkembang untuk menyelesaikan setiap permasalahan.

\section{METODE PENELITIAN}

Penelitian ini menggunakan PTK atau Penelitian Tindakan Kelas. Tindakan kelas ini bertujuan untuk mengetahui tingkat kemampuan berpikir kreatif siswa kelas 2 SD yang dilakukan di SD Muhammadiyah 3 Surabaya. Kemampuan berpikir kreatif siswa kelas 2 SD Muhammadiyah 3 Surabaya dalam mengajukan masalah sebelum pembelajaran berbasis Open Ended Problems dimulai dapat dilihat dengan melakukan tes awal pada cara berpikir kreatif siswa. Tes awal berpikir kreatif siswa ini berfungsi sebagai evaluasi awal untuk mengetahui adanya perubahan tingkat kemajuan berpikir kreatif siswa. Apabila terdapat perubahan tingkat kemajuan berpikir kreatif siswa positif, ini berarti terdapat peningkatan kemampuan berpikir kreatif siswa, (Afiani \& Putra, 2017).

Pada penelitian ini peneliti berkolaborasi dengan guru kelas 2 SD Muhammadiyah 3 Surabaya, yaitu Ade
Venti Noer Oktavia, S.Pd. Prosedur penelitian ini meliputi: perencanaan, pelaksanaan tindakan, observasi, dan refleksi menurut Kemmis (Afiani \& Putra, 2017). Langkah - langkahnya sebagai

berikut: (1) perencanaan (planning), langkah-langkah dalam tahap ini adalah mengadakan pengamatan awal dengan mengamati keadaan sekolah, guru, maupun siswanya; mendiskusikan tentang pembelajaran matematika yang meningkatkan kemampuan berpikir kreatif; membuat jadwal penelitian dan berkolaborasi dengan guru kelas; menyiapkan perangkat pembelajaran yaitu LKS dan RPP; menyiapkan instrumen penelitian yang meliputi lembar test dan lembar non test. (2) pelaksanaan tindakan (action) langkah langkah dalam tahap ini adalah memberikan penjelasan secara menarik dalam proses pembelajaran; menyampaikan tujuan pembelajaran atau kompetensi dasar yang ingin dicapai; menyajikan informasi tentang materi bilangan cacah (999) melalui model pembelajaran Open Ended Problems; membagikan lembar kerja siswa (LKS) berbasis Open Ended Problems.; meliputi pemberian masalah, memahami masalah, pemecahan masalah, membandingkan dan mediskusikan, menyimpulkan. Dalam pendekatan Open Ended Problems guru 
menyajikan permasalahan kepada siswa dengan solusinya tidak hanya ditentukan hanya dengan satu jalan atau cara. (3) observasi (observation), langkah-langkah dalam tahap ini adalah peneliti melakukan pengamatan; peneliti melakukan pengamatan terhadap proses pembelajaran dan pengamatan terhadap guru dalam mengelola kelas, serta mengamati aktivitas siswa selama pembelajaran berbasis Open Ended Problems berlangsung; memberikan penilaian hasil tes berpikir kreatif siswa yang telah dikerjakan secara individu dan penilaian non tes kepada siswa saat proses pembelajaran berlangsung, kemudian (4) refleksi (reflection), langkah - langkah pada tahap ini adalah menganalisis dan merangkum hasil observasi; menganalisis hasil tes berpikir kreatif siswa.

Menurut Siswono (Ramadhani \& Nuryanis, 2017) bahwa pengembangan level tingkat berpikir kreratif ini terdiri dari lima tingkatan yaitu:

1. Tingkat berpikir kreatif 4 (sangat kreatif).

2. Tingkat berpikir kreatif 3 (kreatif).

3. Tingkat berpikir kreatif 2 (cukup kreatif),

4. Tingkat berpikir kreatif 1 (kurang kreatif),

5. Tingkat berpikir kreatif 0 (tidak kreatif). Fase pembelajaran berbasis pengajuan masalah adalah pada tabel 1 berikut:

Tabel 1: Tingkat Berpikir Kreatif Matematis (TBKM) dari Siswono.

\begin{tabular}{|c|l|}
\hline $\begin{array}{c}\text { Tingkat Berpikir Secara } \\
\text { Kreatif Matematis }\end{array}$ & \multicolumn{1}{c|}{ Deskripsi } \\
\hline $\begin{array}{c}\text { Level 4 } \\
\text { (sangat kreatif) }\end{array}$ & $\begin{array}{l}\text { Siswa dapat menjawab lebih dari satu jawaban maupun cara } \\
\text { penyelesaiannya atau membuat masalah yang berbeda-beda dengan } \\
\text { lancar dan fleksibel. }\end{array}$ \\
\hline $\begin{array}{c}\text { Level 3 } \\
\text { Kreatif) }\end{array}$ & $\begin{array}{l}\text { Siswa dapat menjawab dengan cara penyelesaian yang berbeda } \\
\text { meskipun tidak lancar. Selain itu siswa dapat membuat masalah yang } \\
\text { berbeda dengan lancar meskipun jawaban masalah tersebut hanya satu } \\
\text { jawaban atau membuat masalah yang baru dengan jawaban berbeda. }\end{array}$ \\
\hline $\begin{array}{c}\text { Level 2 } \\
\text { (Cukup Kreatif) }\end{array}$ & $\begin{array}{l}\text { Siswa dapat membuat satu jawaban atau masalah yang berbeda dari } \\
\text { kebiasaan umum meskipun tidak dengan fleksibel atau fasih, atau } \\
\text { mampu menunjukkan berbagai cara penelesaian yang berbeda dengan } \\
\text { fasih meskipun jawaban yang dihasilakan tidak baru. }\end{array}$ \\
\hline $\begin{array}{c}\text { Level 1 } \\
\text { (Kurang Kreatif) }\end{array}$ & $\begin{array}{l}\text { Siswa tidak mampu menjawaban atau membuat masalah yang berbeda, } \\
\text { meskipun salah satu kondisi berikut dipenuhi, yaitu cara penyelesaian }\end{array}$ \\
\hline
\end{tabular}




\begin{tabular}{|c|l|}
\hline $\begin{array}{c}\text { Level 0 } \\
\text { (Tidak Kreatif) }\end{array}$ & $\begin{array}{l}\text { yang dibuat berbeda-beda atau jawaban/masalah yang dibuat beragam } \\
\text { penyelesaiany atau membuat masalah yang berbeda dengan lancar dan } \\
\text { fleksibel. }\end{array}$ \\
\hline
\end{tabular}

Teknik analisis data yang digunakan oleh peneliti yakni merumuskan simpulan. Teknik analisis data yang digunakan adalah teknik analisis deskriptif. Analisis data ini mengunakan data dari tes kemampuan berpikir kreatif siswa dan non tes yang berdasarkan observasi selama proses pembelajaran berlangsung. Tes berpikir kreatif siswa dilakukan sebelum dan sesudah pembelajaran kemudian hasil dari kedua tes tersebut dapat diketahui perubahan kemampuan berpikir kreatif siswa, (Afiani \& Putra, 2017).

Hasil tersebut dapat diklasifikasikan menjadi 5 tingkat kemampuan berpikir kreatif dan dapat dihitung persentasenya. Persentase dari perubahan tingkat kemampuan berpikir kreatif siswa dihitung dengan rumus:

Presentase perubahan kemajuan tingkat KBK siswa, (Afiani \& Putra, 2017)

$$
=\frac{\text { Jumlah perubahan kemajuan tingkat KBK siswa }}{\text { Jumlah seluruh siswa }} \times 100
$$

Kemudian analisis ke dua menggunakan non tes yang berdasarkan observasi berdasarkan berpikir kreatif yang dilakukan sebelum dan sesudah dengan menerapkan pembelajaran berbasis Open Ended Problems. Teknik penilaian non tes yakni teknik penilaiaan yang pada umumnya untuk menilai kepribadian anak seutuhnya sehingga bersifat komprehensif. Artinya, penilaian non tes ini digunakan untuk menilai berbagai aspek dari individu yang meliputi sikap, ucapan, dan lain-lain yang berhubungan dengan kegiatan belajar. Untuk mengukur data mengenai sikap aktif dalam proses pembelajaran, teliti, dan percaya diri siswa dalam berpikir kreatif, masing - masing tersebut menggunakan 4 pernyataan, menggunakan skor skala 4 dengan keterangan sebagai berikut:

\section{Tabel Skor Kriteria Penilaian}

\section{Sikap}

(Penilaian Pencapaian Kompetensi Sikap, 2013)

Untuk mengukur data mengenai aktivitas siswa seperti teliti, dan percaya diri siswa dengan rumus sebagai berikut: 
$=\frac{\text { Jumlah skor yang diperoleh }}{\text { Skor maksimal }} \times 100$

(Arikunto, 2010)

Menentukan predikat berdasarkan persentase yang diperoleh siswa, dengan klasifikasi sebagai berikut:

\begin{tabular}{|c|c|c|}
\hline $\begin{array}{c}\text { Konversi Nilai } \\
\text { (skala 0- 100) }\end{array}$ & Predikat & Klarifikasi \\
\hline $81-100$ & A & SB (Sangat Baik) \\
\hline $66-80$ & B & B (Baik) \\
\hline $51-65$ & C & C (Cukup) \\
\hline $0-50$ & D & K (Kurang) \\
\hline
\end{tabular}

\section{Tabel Indikator Kriteria Penilaian}

(Panduan Penilaian Sekolah Dasar, 2016)

Perubahan kemajuan tingkat kemampuan berpikir kreatif siswa dikatakan positif apabila dari keseluruhan siswa yang ada di kelas mengalami perubahan kemajuan tingkat kemampuan berpikir kreatif .

\section{HASIL PENELITIAN}

Dalam penerapan proses Open Ended Problems pada pembelajaran kelas 2 SD Muhammadiyah 3 Surabaya, ditahap awal peneliti hanya melakukan observasi secara manual terhadap proses pembelajaran di dalam kelas dan mengamati guru yang mengajar ketika memberikan pembelajaran di kelas, bagaimana improvisasi guru saat mengajar, penanganan terhadap siswa saat proses pembelajaran juga respon dari para siswa tersebut, ditemukan saat proses pembelajaran pada siswa

Kelas 2 SD Muhammadiyah 3 Surabaya belum menggunakan model pembelajaran atau lebih mengarah pada cara pembelajaran konvensional selain itu penanganan yang kurang menarik terhadap siswa. Sehingga siswa tidak aktif dan kebanyakan dari mereka tidak tertarik saat pembelajaran berlangsung, banyak dari mereka yang bersenda gurau dengan teman sebangku.

Kemudian peneliti melanjutkan kegiatan menerapkan proses Open Ended Problems pada siklus 1. Peneliti membuat RPP atau rancangan pelaksanaan pembelajaran dengan berkolaborasi bersama guru kelas 2 SD Muhammadiyah 3 Surabaya yakni Ade Venti Noer Oktaviani, S.Pd. Selanjutnya, peneliti dan guru kelas berdiskusi terkait bagaimana cara penyampaian pada opening pembelajaran. Masuk pada inti pembelajaran, guru menampilkan sebuah tayangan video bilangan cacah (999) pada layar LCD dengan menerapkan proses pembelajaran Open Ended Problems. Proses penerapan model Open Ended Problems yakni guru memberikan kesempatan kepada siswa dalam menyampaikan ide, menjawab sebuah pertanyaan, menemukan solusi dari setiap permasalahan selama proses pembelajaran berlangsung, dan 
memberikan stimulus agar siswa bisa percaya diri dalam menyampaiakan ide dan mencari solusi dari setiap permasalahan. Dalam menerapkan pembelajaran model Open Ended Problems pada siklus 1 selama proses pembelajaran berlangsung

guru memberikan materi dengan menggunakan media video. Saat proses tayangan video berlangsung, siswa nampak teratrik dengan materi yang disampaikan, namun terdapat beberapa siswa yang tidak memperhatikan saat pembelajaran dimulai salah satunya masih ada siswa yang ngobrol dengan teman sebangku. Setelah proses pemutaran video selesai terdapat respon dari para siswa yang sangat antusias. Guru memberikan kesempatan kepada siswa untuk menganalisis isi dari materi yang sudah disampaikan. Siswa mulai berperan aktif dalam berinteraksi di dalam proses pembelajaran dengan mengajukan pertanyaan dan menjawab pertanyaan baik itu dari guru maupun teman. Selain itu, mereka juga diberi kesempatan menanggapi apa saja selama proses pembelajaran berlangsung di dalam kelas. Nampak belum merata dari siswa kelas 2 yang percaya diri untuk menyampaikan ide atau pendapat dan juga belum sepenuhnya bisa untuk menemukan solusi dari setiap permasalahan, sehingga dalam proses penerapan Open Ended Problems dipembelajaran siklus 1, dikatakan belum maksimal karena hasil dari penerapan proses Open Ended Problems pada siswa kelas 2 belum mencapai keseluruhan siswa yang bisa mengikuti proses pembelajaran model Open Ended Problems. Sehingga menjadikan evaluasi yang kemudian peneliti melakukan penelitian lebih lanjut di tahap siklus 2 .

Pada siklus 2 peneliti tetap berkolaborasi dengan guru kelas 2 . Langkah awal membuat RPP tau rancangan pelaksanaan pembelajaran terlebih dahulu, dengan suasana yang berbeda peneliti bersama guru memberikan sedikit semangat kepada siswa ketika mengikuti pembelajaran berlangsung seperti halnya ice breaking yang berkaitan dengan materi belajar, kemudian masuk pada inti pembelajaran ditahap siklus 2 guru menayangkan video yang berisikan materi bilangan cacah (999) disiklus 2 terdapat respon yang lebih antusias dari para siswa karena sebelum memulai pebelajaran mereka diajak mengikuti ice breaking bersama peneliti dan guru, saat menayangkan video para siswa tertib dan mengamati dengan baik materi yang disampaikan dalam video, setelah materi disampaikan melalui video selesai penerapan Open Ended Problems 
dilakukan oleh guru dengan memberikan stimulus kepada siswa agar seluruh siswa kelas 2 timbul rasa percaya diri dalam menyampaikan ide atau pendapat mereka. Guru memberikan stimulus dengan memberikan pertanyaan sederhana kepada semua siswa mengajukan sebuah pertanyaan yang dikemas dengan permainan dan terdapat progress yang siknifikan terkait penerapan proses pembelajaran model Open Ended Problems, semua siswa sudah mulai percaya diri dan antusias untuk menyampaikan pemahaman, mengajukan pertanyaan dan menjawab pertanyaan bahkan ada siswa yang bisa menanggapi sebuah pertanyaan dari temannya.

Dengan demikian proses penerapan model Open Ended Problems memberikan sebuah progress yang siknifikan dalam proses pembelajaran di kelas 2 SD Muhammadiyah 3 Surabaya.

Perihal hasil kemajuan tingkat berpikir kreatif siswa kelas 2 SD Muhammadiyah 3 Surabaya, maka 12 dari 26 siswa kelas 2 tahap siklus 1 mengalami kemajuan tingkat berpikir kreatifnya, oleh karena itu, hasil persentase peningkatannya, dapat dihitung sebagai berikut

$=\frac{\text { Jumlah perubahan kemajuan tingkat KBK siswa }}{\text { Jumlah seluruh siswa }} \times 100 \%$ $=\frac{12}{26} \times 100 \%$
$=46,15 \%$

Kemudian dari segi penilaian non tes dengan observasi aktifitas penilaian sikap siswa antara lain, ketelitian dan keaktifan pada saat sesi tanya jawab serta diskusi setelah melihat tayangan video dengan menerapkan pembelajaran Open Ended Problems siswa kelas 2 SD Muhammadiyah 3 Surabaya terdapat peningkatan sebagai berikut,

$$
\begin{aligned}
& =\frac{\text { Jumlah skor yang diperoleh }}{\text { Skor maksimal }} \times 100 \\
& =\frac{15}{20} \times 100 \\
& =75
\end{aligned}
$$

Dari hasil yang diperoleh dapat dikatakan bahwa dengan menerapkan pembelajaran berbasis Open Ended Problems berbantuan video pembelajaran pada siklus 1 , tingkat kemampuan berpikir kreatif siswa kelas 2 mengalami peningkatan sebesar $46,15 \%$ dengan rata - rata nilai 75 yang mana masuk dalam kategori kurang, akan tetapi persentase dan nilai yang dihasilkan tersebut masih belum memenuhi karena perubahan kemajuan tingkat berpikir kreatif siswa dikatakan positif apabila $\geq 75 \%$ dari keseluruhan siswa di kelas mengalami perubahan kemajuan tingkat kemampuan berpikir kreatif dengan mencapai indikator kriteria penilaian $\geq 75$. Hal ini disebabkan pada 
siklus 1 terdapat beberapa kekurangan yang perlu diperbaiki yaitu,

1. Siswa masih belum terbiasa mengerjakan LKS dengan lancar dan masih bingung dengan maksud perintah yang ada pada LKS serta informasi yang didapatkan.

2. Siswa belum terbiasa dalam mengungkapkan pendapat mereka sendiri dan belum terbiasa menanggapi temannya saat menjelaskan

3. Diperlukan waktu lebih lama sehingga proses pembelajaran berjalan lancar dan semua materi disampaikan dengan baik.

Kegiatan pada siklus 1 terdapat beberapa kekurangan sehingga perlu diadakan perbaikan tindakan pada siklus 2. Pada tindakan siklus 2 telah mengalami perbaikan diantaranya sebagai berikut :

1. Siswa mulai bisa mengikuti arahan/petunjuk dalam mengerjakan LKS secara perlahan dan sudah mulai familiar dengan soal yang dihadapi.

2. Siswa mulai percaya diri dalam mengungkapkan pendapatnya sendiri serta mulai terbiasa menanggapi pendapat teman dengan memahami konteks permasalahan.
3. Memanfaatkan waktu dengan sebaik - baiknya dengan cara mengatur kondisi secara kondusif serta se - efisien mungkin namun para siswa tetap senang dalam proses pembelajaran.

Setelah perbaikan dilakukan pada siklus 2 maka hasil perolehan data menunjukkan bahwa dengan menerapkan pembelajaran Open Ended Problems berbantuan video pembelajaran, maka 21 dari 26 siswa kelas 2 di tahap siklus 2 mengalami perubahan kemajuan tingkat berpikir kreatifnya dari tes awal sampai ke tahap siklus 2. Oleh karena itu, hasil persentase peningkatannya dapat dihitung, sebagai berikut:

Persentase perubahan kemajuan tingkat KBK Siswa

$=\frac{\text { Jumlah perubahan kemajuan tingkat KBK siswa }}{\text { Jub }} \times 100 \%$

$=\frac{21}{26} \times 100 \%$

$=80,76 \%$

Dilanjutkan penilaian non tes pada siklus 2 yang meliputi penilaian sikap antara lain, ketelitian dan keaktifan pada saat sesi tanya jawab serta diskusi setelah melihat video pembelajaran dengan menerapkan model Open Ended Problems pada siswa kelas 2 SD Muhammadiyah 3 Surabaya terdapat peningkatan sebagai berikut. 


$$
\begin{aligned}
& =\frac{\text { Jumlah skor yang diperoleh }}{\text { Skor maksimal }} \times 100 \\
& =\frac{21}{20} \times 100 \\
& =95
\end{aligned}
$$

Berdasarkan data yang telah diperoleh, maka dapat diklasifikasikan kemampuan berpikir kreatif siswa dan indikator kriteria penilaian dari tes awal, tahap siklus 1, dan tahap siklus 2 berdasarkan tingkatannya pada tabel 2

\begin{tabular}{|c|c|c|c|c|c|c|c|}
\hline \multirow{3}{*}{ Tingkat KBK } & \multirow{3}{*}{$\begin{array}{c}\text { Keterangan } \\
\text { KBK }\end{array}$} & \multicolumn{6}{|c|}{ Jumlah Siswa } \\
\hline & & \multicolumn{2}{|c|}{ Test Awal } & \multicolumn{2}{|c|}{ Siklus 1} & \multicolumn{2}{|c|}{ Siklus 2} \\
\hline & & $\begin{array}{l}\text { Jmlh } \\
\text { Siswa }\end{array}$ & Persenta-se & $\begin{array}{l}\text { Jmlh } \\
\text { Siswa }\end{array}$ & $\begin{array}{l}\text { Persenta- } \\
\text { se }\end{array}$ & $\begin{array}{l}\text { Jmlh } \\
\text { Siswa }\end{array}$ & $\begin{array}{l}\text { Persenta- } \\
\text { se }\end{array}$ \\
\hline 4 & Sangat Kreatif & 0 & $0 \%$ & 0 & $0 \%$ & 4 & $15 \%$ \\
\hline 3 & Kreatif & 0 & $0 \%$ & 5 & $19 \%$ & 10 & $38 \%$ \\
\hline 2 & Cukup Kreatif & 4 & $15 \%$ & 13 & $50 \%$ & 9 & $35 \%$ \\
\hline 1 & Kurang Kreatif & 15 & $58 \%$ & 5 & $19 \%$ & 3 & $12 \%$ \\
\hline 0 & Tidak Kreatif & 7 & $27 \%$ & 3 & $12 \%$ & 0 & $0 \%$ \\
\hline \multicolumn{2}{|c|}{ Total Siswa } & 26 & $100 \%$ & 26 & $100 \%$ & 26 & $100 \%$ \\
\hline
\end{tabular}
berikut.

Tabel 2: Tingkat Kemampuan Berfikir Kreatif

Tabel 3: bel Indikator Kriteria Penilaian

\begin{tabular}{|c|c|c|c|c|}
\hline \multirow{2}{*}{ Rentang Nilai } & \multirow{2}{*}{ Konversi } & Test Awal & Siklus 1 & Siklus 2 \\
\cline { 3 - 5 } & & Jmlah Siswa & $\begin{array}{c}\text { Jumlah } \\
\text { Siswa }\end{array}$ & $\begin{array}{c}\text { Jumlah } \\
\text { Siswa }\end{array}$ \\
\cline { 3 - 5 } & $81-100$ & 0 & 0 & 21 \\
\hline 4 & $66-80$ & 4 & 15 & 4 \\
\hline 3 & $51-65$ & 12 & 7 & 1 \\
\hline 2 & $0-50$ & 10 & 4 & 0 \\
\hline 1 & $\mathbf{2 6}$ & $\mathbf{2 6}$ & $\mathbf{2 6}$ \\
\hline \multicolumn{2}{|c|}{ Total Siswa } &
\end{tabular}

Hasil persentase dan nilai dari kriteria penilaian tersebut sudah observasi aktivitas siswa telah mencapai memenuhi karena perubahan kemajuan indikator kriteria penilaian dan dikatakan tingkat kemampuan berpikir kreatif siswa bahwa dengan menerapkan dikatakan positif apabila dari pembelajaran Open Ended Problems keseluruhan siswa di kelas mengalami berbantuan video pembelajaran pada perubahan kemajuan tingkat siklus 2, tingkat kemampuan berpikir kemampuan berpikir kreatif. Dengan kreatif siswa kelas 2 mengalami demikian, pada tahap siklus 2 dapat peningkatan sebesar $80,76 \%$ dengan dikatakan tingkat kemampuan berpikir rata - rata indikator kriteria penilaian kreatif siswa meningkat.

yakni 95. Persentase dan indikator 
KESIMPULAN

Dalam proses penerapan Open Ended Problems itu sendiri pada tahap awal belum ada sebuah model pembelajaran yang menarik atau lebih mengarah kepada pembelajaran secara konvensional di kelas 2 SD Muhammadiyah 3 Surabaya, pada siklus 1 penerapan model Open Ended Problems terdapat sedikit perubahan pada siswa yakni siswa sudah mulai aktif dalam menyampaikan ide atau pendapat mereka, di tahap siklus 2 penerapan model Open Ended Problems terdapat progress yang lebih baik dan sangat siknifikan yang nampak pada siswa, hampir seluruh siswa secara merata timbul rasa percaya diri untuk menyampaikan ide atau pendapat mereka dan mulai bisa menanggapi juga mencari solusi dari setiap pertanyaan.

Terlihat juga adanya perubahan berpikir kreatif mereka pada siklus 1 sebesar 46, 15\% dengan mencapai indikator kriteria penilaian 75 dan pada siklus 2 sebesar $80,76 \%$ dengan mencapai indikator kriteria penilaian yakni 95. Dalam. Hal ini menunjukkan bahwa penerapan model Open Ended Problems terdapat kemajuan pembelajaran yang baik untuk siswa dan adanya peningkatan pada kemampuan berpikir kreatif siswa dan kelas 2 SD Muhammadiyah 3 Surabaya.

\section{DAFTAR PUSTAKA}

Abdurrahman, M. (2003). Pendidikan Bagi Anak Berkesulitan Belajar. Jakarta: Rhineka Cipta

Afiani, K. D. A., \& Putra, D. A. (2017). Peningkatan Kemampuan Berpikir Kreatif Pada Siswa Kelas III SD Melalui Pembelajaran Berbasis Pengajuan Masalah . ELSE (Elementary School Education Journal), 1(1).

Amir, F. M., \& Wardana, M. D. K. (2017). Pengembangan Domino Pecahan Berbasis Open Ended Untuk Meningkatkan Kemampuan Berpikir Kreatif Siswa SD. Jurnal Pendidikan Matematika FKIP Univ. Muhammadiyah Metro, 6(2).

Amir, M. F., \& Wardana, M. D. K. (2017). Pengembangan Domino Pecahan Berbasis Open Ended Untuk Meningkatkan Kemampuan Berpikir Kreatif Siswa SD. Pendidikan Matematika, 6(2).

Arikunto, S. (2010). Prosedur Penelitian Suatu pendekatan Praktek. Jakarta: Rineka Cipta.

Biliya A, B. (2015). Penerapan Model Open Ended untuk Meningkatkan Keterampilan Proses dan Hasil Belajar Siswa Kelas V SDN 1 Repaking - Wonosegoro Boyolali. Jurnal Pendidikan Dan Kebudayaan, 5(1), 78-91. 
Kawuryan, S. P. (2013). Karakteristik Siswa SD Kelas Rendah dan Pembelajarannya. Yogyakarta: PPSD FIP UNY.

Mardhiyana, D., \& Sejati, E. O. W. (2016). Mengembangkan Kemampuan Berpikir Kreatif dan Rasa Ingin Tahu Melalui Model Pembelajaran Berbasis Masalah. PRISMA, 1(1)

Nada, I., Utaminingsih, S., \& Ardianti, S. D. (2018). Penerapan Model Open Ended Problems Berbantuan CD Pembelajaran Untuk Meningkatkan Kemampuan Berpikir Kreatif Siswa Kelas IV SD 1 Golantepus. JPSD, 4(2).

Panduan Penilaian Sekolah Dasar. (2016).

Pujiati, Kanzunnudin, M., \& Wanabuliandari, S. (2018). Penerapan Contextual Teaching and Learning Berbantu Blok Pecahan Untuk Pecahan Untuk Peningkatan Pemahaman Konsep Siswa. Jurnal Ilmiah Pendidikan Matematika, 1(1).

Putranti, A. D., Wannabuliandari, S., \& Santoso. (2021). Penerapan Model Pembelajaran Creative Problem Solving Berbantuan Media Konkret Untuk Meningkatkan Kemampuan Berpikir Kreatif Pada Siswa Kelas IV SD 2 Garung Lor Kudus. Jurnal IImiah Mitra Swara Ganesha, 8(1).

Ramadhani, D., \& Nuryanis. (2017). Analisis Kemampuan Berpikir Kreatif Matematis Siswa SD dalam Menyelesaikan Open - Ended Problem. JPSD, 4(2).

Taufik, M. (2012). Pengaruh Pendekatan Open Ended Terhadap Motivasi Belajar dan Kemampuan Pemecahan Masalah Matematis Siswa . AgriSains, 5(1).

Wanelly, W., \& Fauzan, A. (2020). Pengaruh Pendekatan Open - Ended dan Gaya Belajar Siswa Terhadap Kemampuan Berpikir Kreatif Matematis. Jurnal Basicedu , 4(3), 523-533.

Yudianto, A. (2017). Penerapan Video Sebagai Media Pembelajaran. Seminar Nasional Pendidikan 2017. Sukabumi: Universitas Muhammadiyah Sukabumi 